\title{
オクラさく果の食品物性と化学成分に及ぼす貯蔵温度の影響
}

\author{
（第 1 報）オクラさく果の鮮度保持について
}

\section{田尻尚 士*}

Effect of the Storage temperatures on Changes of Food physical properties and

Composition of Okra Pods (Hibiscus esculentus L.)

Part I Studies on Keeping Quality of Okra Pods (Hibiscus esculentus L.)

Takashi TAJIRI**

\section{Summary}

Effect of storage temperatures on the freshness, food physical properties and changes in the chemical composition of Okra pods (Hibisucus esculentus L.). The stored under 1, 5, 10, 15, 20 and $-20^{\circ} \mathrm{C}$ temperature for the evaluation of the optimum storage temperature.

1. Food physical properties: Needle-invasion, elasticity and viscosity of the samples were deteriorated greatly after $5 \sim 7$ days of storage at $1,5^{\circ} \mathrm{C}$ and $20^{\circ} \mathrm{C}$ respectively. The stored at 10 and $15^{\circ} \mathrm{C}$ and $-20^{\circ} \mathrm{C}$, Okra maintained the freshness for around 25 days.

2. Color: The samples became brown in the same manner as the deterioration tendency of food physical properties. Also, it was found that the browning phenomenon detected by the method used in this study was about 3 days-earlier than the macroscopic observation.

3. Total ascorbic acid content: Unde $1,5^{\circ} \mathrm{C}$ and $20^{\circ} \mathrm{C}$ storage the decrease in the total ascorbic acid content was rapid in a high frequency compared to the deterioration degree of food physical properties. The decreasing tendency under at $10,15^{\circ} \mathrm{C}$ and $-20^{\circ} \mathrm{C}$ were slower, and the rates were reprssed singnificantly.

4. Total pectin content: The decrease in the total pectin content during the storage was quite similer to the changing profile of viscosity. At each storage temperature, the decrease in the total pectin content generally started $3 \sim 5$ days after the initiations of deterioration of food physical properties and reduction of total ascorbic acid content. The decreasing rate was slightly high during 7-10 days of storage at $1,5^{\circ} \mathrm{C}$ and $20^{\circ} \mathrm{C}$, and during early period of storage at $10,15^{\circ} \mathrm{C}$ and $-20^{\circ} \mathrm{C}$. After no decrease was observed at 10,15 , and $-20^{\circ} \mathrm{C}$ storage.

In conclusion, the optimum storage temperature of Okra pods was $10 \sim 15^{\circ} \mathrm{C}$, and the limiting period for storage was about $20 \sim 25$ days for fresh.

(Received Nov. 28, 1985)

* 近畿大学農学部食品加工学教室

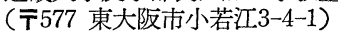

**Laboratry of Food process, Faculty of Agriculture. Kinki University (3-4-1, Kowakae, Higshi-Osaka, Osaka 577)

\section{緒言}

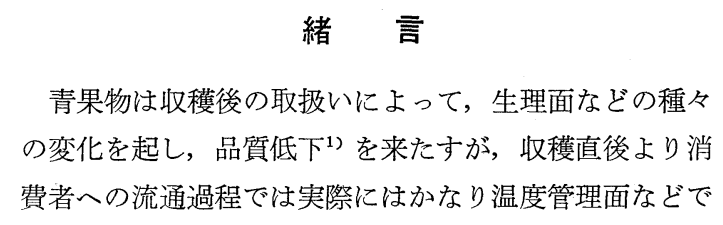

青果物は収穫後の取扱いによって, 生理面などの種々 費者への流通過程では実際にはかなり温度管理面などで 
粗雑に取扱われ，その結果として見かけ上は正常である が物理的品質や内容成分が劣化し，品質劣化がかなり進 行している場合が多い。

嗜好性に富む果菜類の一つであるオクラは最近消費量 が著しく増加する傾向にある。その独特な食味は粘質物 であるペクチン，ガラクタンおよびアラバンの混合物で ある多糖類 $\left.{ }^{2}, 3\right)$ に由来している。本報告では, 収穫から 消費者への流通過程中の温度状態を想定し, 貯蔵温度を $1{ }^{\circ} \mathrm{C}\left( \pm 1^{\circ} \mathrm{C}\right) \sim 20^{\circ} \mathrm{C}$ および対照区として $-20^{\circ} \mathrm{C}$ 凍結区 を設定し, 各貯蔵温度下での食品物性（針入度, 弾力 度, 粘性度および色調) および内容成分としての総アス コルビン酸と総ペクチン含有量を測定し，同時に肉眼に よる外観変化を測定し，これら結果より適正貯蔵温度を 検討した。

\section{実験材料と方法}

実験材料は，兵庫県川西市産のオクラさく果 “グリー ンスター (変種)”の開花結実後 6 日のさく果を用いた。 オクラさく果の大きさは長さ $6.0 \sim 8.0 \mathrm{~cm}$ ，重さ6.5 9.4 $\mathrm{g}$ で収积直後 30 分以内に緑色ネット袋 $(10 \mathrm{mesh})$ に10 個体を投入，発泡スチロール血上に整置したのち熱収縮 ポリビニリデンコロライド $(20 \mu$ 厚, $15 \times 10 \mathrm{~cm})$ 包装袋 でシュリンクパック包装を行い，直ちに $1 ， 5 ， 10,15$ および $20^{\circ} \mathrm{C}$ 亿貯蔵した。な掠， $-20^{\circ} \mathrm{C}$ 貯藏区は収穫後直 ちに 85 90 $\mathrm{C}$ の熱湯中で 3 分間ブランチング処理を行っ た後， $-20^{\circ} \mathrm{C}$ のリザーに貯蔵した。

針入度, 弾力度扔上び粘性度は, テコによる抵抗力を I C 回路により增幅させる自記記録装置つきレオ・メー ターで測定した。

粘性度は, オクラさく果全果に 5 倍量の水を加えてホ モジナイズし， 42 mesh のステンレス製篩を用いて裹ご しを行った滤液をビーカーに移した後，レオ・メーター を用いて測定した。

総アスコルビン酸はオクラさく果全果を（果柄部除 去）ホモジナイズした後，12,000 rpmで遠心分離を行い 上澄液を螢光分析法 ${ }^{4}$ ）（励起波長 $350 \mathrm{~nm}$, 螢光波長 430 $\mathrm{nm}$ ）で測定した。また，総ペクチンは，オクラさく果 全果（果柄部除去）をホモジナイズし，8,000rpm で遠 心分離した上澄液を用いて, カルバゾール比色法 ${ }^{5}$ （吸 光度 $520 \mathrm{~nm}$ ）で測定した。色調は色差計によるハンター 表色法 $\left.{ }^{6}\right)$ で Lb/ $|\mathrm{a}|$ として表示した。

鮮度保持評価は，鮮度指数を 8 段階に設定し，20名に
て評価決定した。

\section{実 験 結 果}

\section{1. 針 入 度}

オクラさく果の組織密度の保持性と, 咀しゃく時の歯 当り感を知るために測定したが，これらの結果は Fig. 1 に示した。

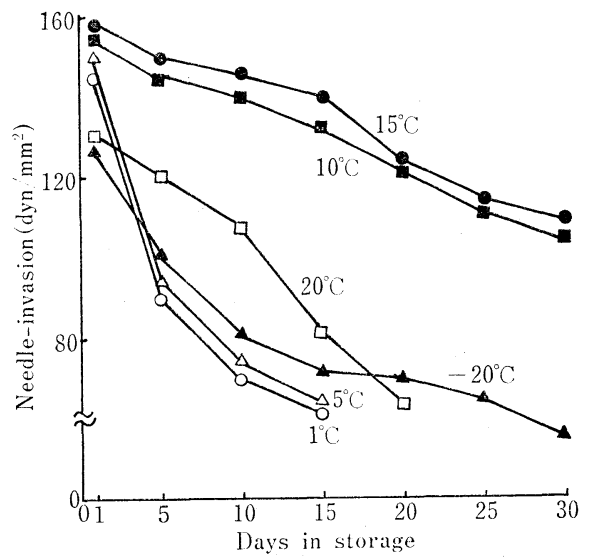

Fig. 1 Changes in needle-invasion of Okra pods during storage

針入度は貯蔵温度に大きく影響され，全般的に低温区 の $1,5{ }^{\circ} \mathrm{C}$ および- $20^{\circ} \mathrm{C}$ 凍結区では貯蔵 5 日間で収穫時 と比較すれば $40 \%$ 前後針入度は低下した。

一方，中温区の $10 ， 15^{\circ} \mathrm{C}$ 区ではわずかに $12 \%$ 前後と極 めて低下率は低く, 常温 $20^{\circ} \mathrm{C}$ 区はこれらの両温度区のほ ぼ中間的低下率で $26 \%$ となった。低温区は貯蔵 5 日より 15日にわたって緩慢な状態で針入度は低下し，貯蔵15日 間で収穫時に比して $60 \%$ の低下率を示した。見かけ上は 貯蔵10日までさほど変化はみられないが，機器測定值で は大きく低下した。低温区では組織密度的にみて貯蔵初 期にかなり急速に鮮度の低下寸ることが認められた。

一方， $-20^{\circ} \mathrm{C}$ 区では眝蔵初期での組織密度は低下が急 速であり，10日目上り除々に低下し貯蔵30日間で低下率

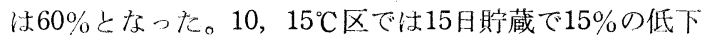
率を示し, 組織的にみて鮮度保持性は良好で, 肉眼的に はほとんど差は認められなかった。これらの結果より， 貯蔵温度 $5{ }^{\circ} \mathrm{C}$ より $10^{\circ} \mathrm{C}$ 区が極めて有効であることがわ かった。

\section{2. 弾 力 度}

オクラさく果の組織強度の保持性を知るために測定し た。この結果は Fig. 2 に示した。 


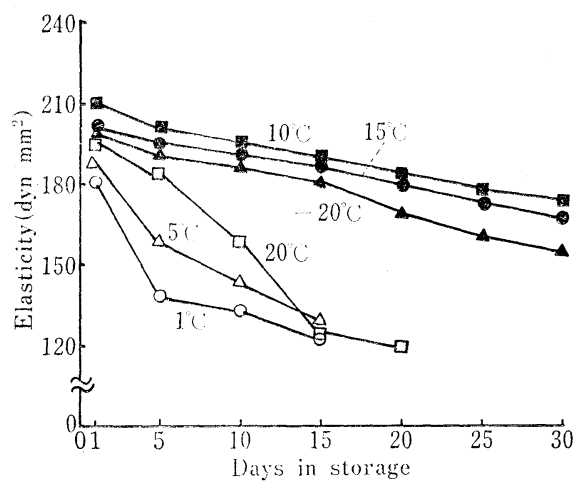

Fig. 2 Changes in elasticity of Okra during storage

全般的に各貯蔵温度区とも弾力度の保持性は， $-20^{\circ} \mathrm{C}$ 区以外針入度の結果と類似した様相を示した。貯蔵 5 日 間で 1，5 ㄷは大きく弾力度は低下し， $1{ }^{\circ} \mathrm{C}$ 区 $36 \%$ ， 5 ํ区は23\%，20区は15\%と大きく低下した。しか し， $10^{\circ} \mathrm{C}$ 区と $15^{\circ} \mathrm{C}$ 区は $10 \%$ 前後で弾力保持性は良好で,

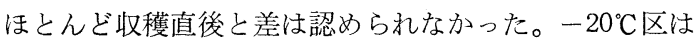
$10 ， 15^{\circ} \mathrm{C}$ 区と類似した状態であった。

貯蔵15日間での弾力度の低下率は収穫時に比して 1 , $5 ， 20^{\circ} \mathrm{C}$ 区で $32 \%$ 前後， $10 ， 15{ }^{\circ} \mathrm{C}$ 区で $10 \%$ 前後となり, 中温区での貯蔵が極めて有効であった。 $-20^{\circ} \mathrm{C}$ 区ではオ クラさく果の呼吸や自己消化および乾燥が抑制》゙された ためか針入度に比して極めて弾力性保持が良好であっ た。

\section{3. 粘 性 度}

嗜好性物質の保持力を知るために測定し，その絬果を Fig. 3 に示した。

粘性度は，全般的に各貯蔵温度区とも低下速度は針入

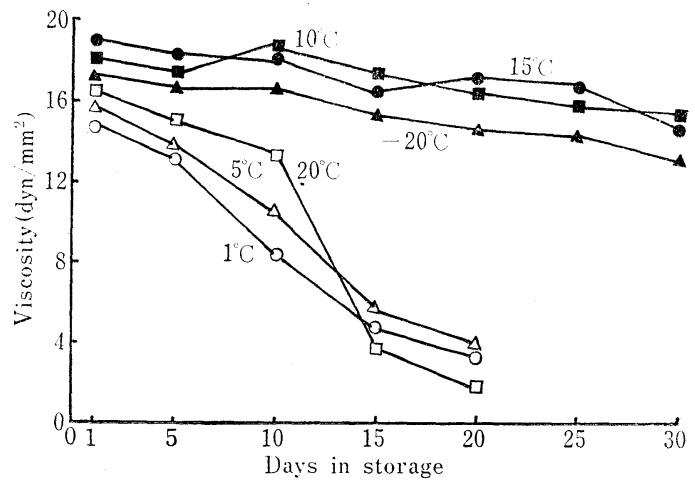

Fig. 3 Changes in viscosity of Okra pods during storage
度, 弾力度より $3 \sim 5$ 日遅延された。とくに, $1,5{ }^{\circ} \mathrm{C}$ および20ㄷ区おいてこの傾向が顕著であった。貯蔵10 日までは緩慢な低下を示し, 以後急激に粘性度は低下し た。これは貯蔵10日間が組織内での粘性物質の保持力が 限界で, 以後は組織の軟化などの劣化により低下率が高 まるためと針入度, 弾力度の低下様相より判断される。 貯蔵 5 日での 1,5 および $20^{\circ} \mathrm{C}$ 区での収穫時に比して の低下率は約 $25 \%$ 前後, $10,15^{\circ} \mathrm{C}$ 区で $8 \%$ 前後であっ た。一方, 15日間貯蔵したものでは前者で70\%, 後者で $12 \%$ 前後となり, 後者において粘性度の保持が顕著であ った。

\section{4. 総アスコルビン酸含有量}

オクラさく果中最も含有量の多いビタミン類の消長を 知るべく測定し，その結果は Fig. 4 に示した。

総アスコルビン酸の消失状況は, 針入度, 弾力度の低 下率と極めて類似した様相を示し，組織の軟化や萎稠と ともに大きく減少し, 貯蔵 5 日間で低温区の $1,5{ }^{\circ} \mathrm{C} 区$ で収穫時に比して $66 \% ， 20^{\circ} \mathrm{C}$ 区で $44 \%$ と大きく減少し た。一方, 中温区の $10,15^{\circ} \mathrm{C}$ 区およびー20ㄷ区では $15 \%$ 前後とかなり減少率は抑制され, 貯蔵10日間では低温区 で $90 \%, 20{ }^{\circ} \mathrm{C}$ 区で $52 \%$, 中温区の $10,15{ }^{\circ} \mathrm{C}$ 区で $27 \%$, $20{ }^{\circ} \mathrm{C}$ 区で $25 \%$ となり，物性度に比してかなり減少率は高 く，急速である。

また，低温区に比して中温区および涷結区が極めて有 意であった。とくに， $-20^{\circ} \mathrm{C}$ 区は貯蔵初期より 30 日間に わたって安定した貯蔵状態を示した。低温貯蔵下では組 織の萎稠や軟化および乾燥などの物理的劣化現象より 1 〜 2 日早く減少が始まり, かつ急速であり, $1 \sim 5{ }^{\circ} \mathrm{C}$ の 低温貯蔵では 5 日前後でほぼ総アスコルビン酸は急激に

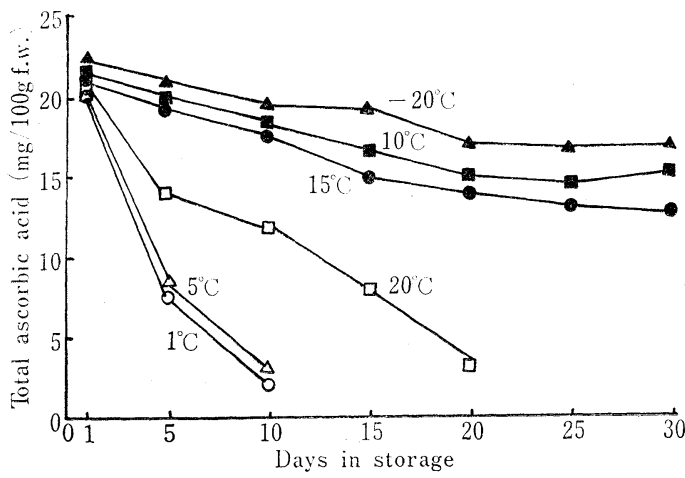

Fig. 4 Changes in total ascorbic acid content of Okra pods during storage 
消失することが認められた。

\section{5. 総ペクチン含有量}

啫好性を左右する粘性物質の代表的成分の保持性を知 るべく測定し，その結果は Fig. 5 に示した。

全般的に中温区の $10 \sim 15^{\circ} \mathrm{C}$ おびー $20^{\circ} \mathrm{C}$ 区は物性度の 低下様相と類似した傾向を示すが，低温区の $1,5{ }^{\circ} \mathrm{C} 区$

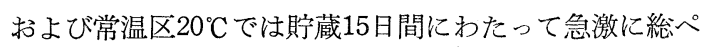
クチン含有量は減少し, 貯蔵 5 日で収穫時に比して 30 $\% ， 15$ 日間で $62 \%$ と大きく低下した。一方，10，15およ びー $20^{\circ} \mathrm{C}$ 区では貯蔵10日まで低下率はやや高く $24 \%$ 前後 となり, 以後緩慢な低下様相を示した。この結果から, 物性度の低下様相より総ペクチン含有量の低下速度は 2 〜 3 日促進される傾向が認められ, 貯蔵10日での低温区 と中温区およびー $20^{\circ} \mathrm{C}$ を比較すれば後者が有意であるこ とが顕著に認められた。

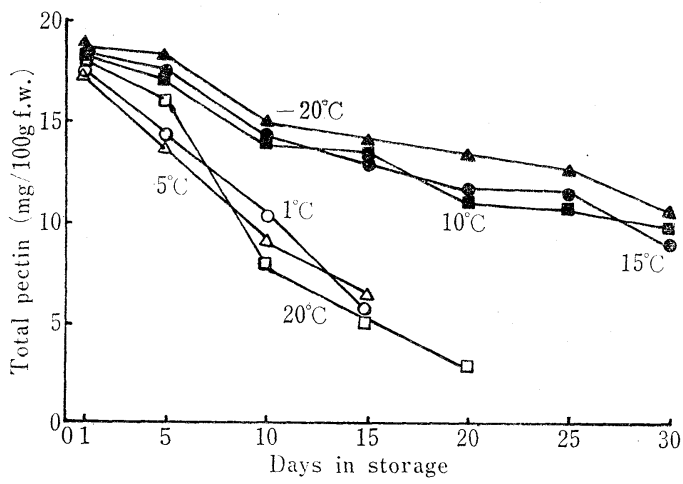

Fig. 5 Changes in total pectent of Okra pods during storage

この結果より，中温区， $-20^{\circ} \mathrm{C}$ 区では嗜好性を十分有 したオクラさく果の貯蔵が可能であった。貯蔵 5 日間で は見かけ上良好なオクラさく果も, 実質的には低温貯蔵 された場合には総ペクチン含有量は収穫時に比して $30 \%$ 低下していることが認められた。

粘性度の低下様相と比較すれば，組織的粘性度は $25 \%$ 低下し, 総ペクチン含有量の低下率は $30 \%$ 強であり, 低 下速度が早く, かつ高いことが認められ, 総ペクチン以 外の粘性物質であるガラクタンおよびアラバンの組織内 での残存性と貯蔵温度との関係など今後の研究が必要で ある。

\section{6. オクラさく果の鮮度保持}

肉眼による見かけ上の鮮度保持性を 8 段階の示度で評 価し，その結果をFig. 6 に示した。

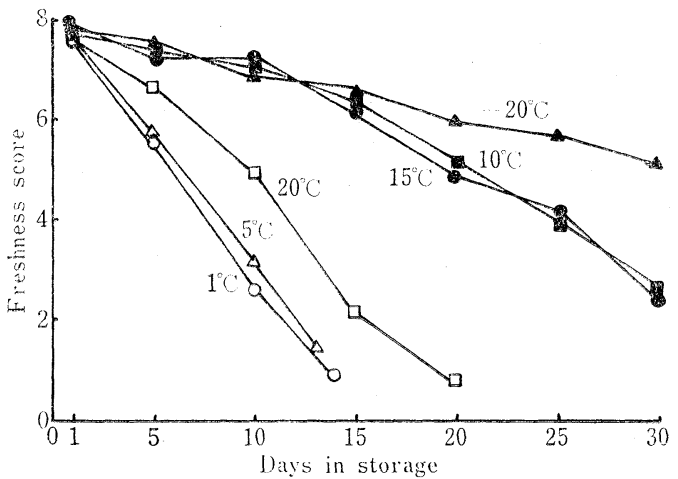

Fig. 6 Changes in freshness of Okra pods during storage

貯蔵中のオクラさく果の鮮度保持性は, 総ペクチン含 有量の消長様相と極めて類似した傾向が認められ, 低温 区の $1 ， 5{ }^{\circ} \mathrm{C}$ 区では貯蔵15日間で大きく，急速に低下し た。貯蔵 5 日間で鮮度 6 程度, 15 日間で商品性がなくな った。中温区の $10,15^{\circ} \mathrm{C}$ おびー $20^{\circ} \mathrm{C}$ 区では貯蔵 5 日で

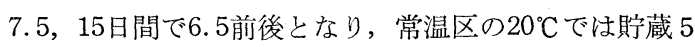
日で 6.5 前後, 15 日間で商品性の限界となった。この結 果から低温区と中温区および常温区での有意性は中温区 が顕著に有意であることが認められた (Fig. 6)。

鮮度低下の様相は, 貯蔵初期 ( $2 \sim 3$ 日) で乾燥を伴 って萎稠が現出し, 次いで変色し, 軟化を経て腐敗へと 進行した。この傾向は低温区で最も顕著で, 中温区およ び常温区ではこれらの現象が 3 5 日低温区より遅延し て現出する傾向となった。 $-20^{\circ} \mathrm{C}$ では貯蔵30白間にわた って緩慢に鮮度低下を来し, 萎稠, 乾燥感は復元時に認 められず，ややさく果のはりを消失し，稜線部が若干形 くずれを呈し，一部裂果するものが認められるが，貯蔵 30日間ではこれらの様相はほとんどなく，40日前後でこ の現象が認められた。

\section{7. オクラさく果の色調変化}

全般的に貯蔵日数の増加に伴い褐色化を呈し, 退色し て腐敗へと進行する。これらの傾向は貯蔵15日までは緩 慢であるが以後かなり急速に褐色化および退色が進行す る。この結果は Fig. 7 亿示した。

低温 $Z$ の $1 ， 5{ }^{\circ} \mathrm{C}$ おび常温 $20^{\circ} \mathrm{C}$ 区ではとくに上述の 傾向が㪟著であった。褐色化および退色度を生鮮時と貯 蔵 5 日で比較すれば，低温区，常温区で $18 \%$ 前後，15日 間で比較すれば25\%前後と極めて大きく退色する。一 方, 中温区の $10,15^{\circ} \mathrm{C}$ おひび- $20^{\circ} \mathrm{C}$ 区では 5 日間での比 


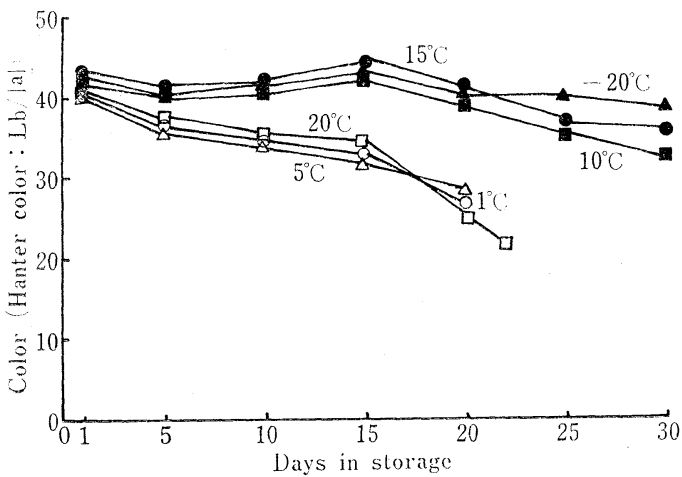

Fig. 7 Changes in color of Okra pods during storage 較で $6 \%$ 前後低下し，15日間で $1.2 \%$ 前後上昇して褐色 化したのち一度暗褐色を呈し, 次いで退色化する特徵が 認められた。とくに低温区では貯蔵15日から20日の5日

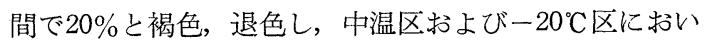
ても $12 \%$ と褐色, 退色現象が認められた。な拉, 雨者と も肉眼に扔いても褐色, 退色化が顕著に認められた。変 色状況はさく果の稜線部より始まり, 次いで果柄部と先 端部へ進行して最終的にはさく果全域に広がり腐敗に至 った。さく果表面に萎稠が認められると同時に褐色化 し, 退色する。

この結果から, 最も安定性を有した $-20^{\circ} \mathrm{C}$ 区は前述の 現象が極めて弱く, 良好な状態で30日間貯蔵が可能であ った。 $-20^{\circ} \mathrm{C}$ 区以外の全区では腐敗直前に黄色化 ${ }^{8)}$ し, さく果のはりが全く認められず，ねじり様を呈した。貯 蔵温度別にみた有意性では, 中温区およびー $20^{\circ} \mathrm{C}$ 区が低 温区および常温区より有意性を有することが認められ た。この有意性は貯蔵10日において最も顕著であった。

\section{考察}

オクラさく果の貯藏性においては全般的傾向としては 食品物性面では，低温区の $1,5{ }^{\circ} \mathrm{C}$ 区および常温区 $20^{\circ} \mathrm{C}$ において貯蔵性は極めて不適格で, 貯蔵 $5 \sim 7$ 日間でオ クラさく果のはりは消失し, 萎稠感を呈し, 貯蔵10１5 日で軟化し腐敗へと進行した。収穫時に比較して, 針入 度では適性貯蔵温度は10 15ㄷ゙あり, 貯蔵限界日数 は，1 $5^{\circ} \mathrm{C}$ で $3 \sim 5$ 日, $10 \sim 15{ }^{\circ} \mathrm{C}$ で $15 \sim 20$ 日，20, 一 $20^{\circ} \mathrm{C}$ で $3 \sim 5$ 日となった。弾力度では適性貯蔵温度は 10 $\sim 15{ }^{\circ} \mathrm{C}$ であり, 貯蔵限界日数は $1 \sim 5{ }^{\circ} \mathrm{C}$ で $3 \sim 5$ 日, $20,-20^{\circ} \mathrm{C}$ で $5 \sim 7$ 日, $10 \sim 15^{\circ} \mathrm{C}$ で20〜25日となった。 針入度, 弾力度は眝蔵 5 日前後で低温区, 凍結区とも
大きく低下し，以後15 20日に急速に低下して腐敗し た。啫好性に大きく関与する粘性度は，低温貯蔵区にお いて針入度, 弾力度より低下様相は $3 \sim 5$ 日遅延され, 貯蔵10日までかなり安定性を示した。

粘性度からみた適性貯蔵温度は10 $15^{\circ} \mathrm{C}$ であり, 貯藏 限界日数は $1 \sim 5{ }^{\circ} \mathrm{C}$ で10日, $20^{\circ} \mathrm{C}$ で10 12日, $10 \sim 15^{\circ} \mathrm{C}$ で30日前後となった。このことから，中温貯蔵区および 凍結区では低下率はかなり抑制され，緩慢な状態で低下 し良好な貯蔵性を示した。

色調変化は, 粘性度と類似した様相で変化し, 低温貯 蔵区および常温貯蔵区で貯蔵15日前後まで低下率はかな り抑制され，中温区および涷結区では䝪蔵初期からほと んど変化なく，貯蔵30日間にわたって良好な貯蔵性を有 した。肉眼的には貯蔵20日前後までほとんど色調変化は 認められなかったが，以後褐色化が認められ退色一と進 行した。適性貯蔵温度は $-20^{\circ} \mathrm{C}$ であり, 貯蔵限界日数は $1 \sim 5{ }^{\circ} \mathrm{C}$ で $5 \sim 7$ 日, $10 \sim 15{ }^{\circ} \mathrm{C}$ で 15 日前後, $-20^{\circ} \mathrm{C}$ で 30 日となった。これらの結果から, 食品物性のみからオク ラさく果の貯蔵性を判定すれば, 適性貯蔵温度は中温区 の10 $15^{\circ} \mathrm{C}$ および凍結区 $-20^{\circ} \mathrm{C}$ が最適であった。

栄養成分および嗜好性に関与する成分の消長について は，全貯蔵温度区とも食品物性度と類似した傾向を示す が，オクラさく果中の貯蔵に伴う総アスコルビン酸の低 下率は低温区において食品物性度の低下速度より急速か つ高く, 一方, 中温区および凍結区では低下率は顕著に 抑制された。適性貯蔵温度は10 15 ${ }^{\circ} \mathrm{C}$ であり, $-20^{\circ} \mathrm{C}$ も 上り効果的であった。貯蔵限界日数は $1 \sim 5{ }^{\circ} \mathrm{C}$ で $2 \sim 3$

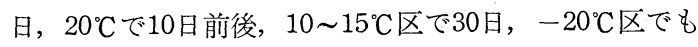
30日間良好な貯蔵性を示した。総ペクチン含有量の低下 様相は粘性度と類似した傾向で総アスコルビン酸の低下 速度より $3 \sim 5$ 日遅延されるが, 貯蔵10日以後は急速に 低下した。この現象は低温区において顕著であった。

中温区および凍結区では低下様相は極めて緩慢で, 低 下率も低いことが認められた。適性貯蔵温度は $10 \sim 15^{\circ} \mathrm{C}$ およびー $20^{\circ} \mathrm{C}$ であり, 貯蔵限界日数は $1 \sim 5{ }^{\circ} \mathrm{C}$ おび $20^{\circ} \mathrm{C}$ では $5 \sim 7$ 日, $10 \sim 15^{\circ} \mathrm{C}$ おびー $20^{\circ} \mathrm{C}$ では $20 \sim 25$ 日 となった。粘性度および総ペクチン含有量の低下が，物 性度や成分より遅延されたのは多糖類であるガラクタン およびアラバンなどの粘性物質が組織の軟化や弱化が進 行しても組織中に残存し, とくに低温中でも粘性物質分 解䤃素の不活性化 ${ }^{93},{ }^{10}$ によって低下率が抑制されたもの と考えられる。 
肉眼的な面からみた鮮度保持性では，前述の測定結果 からかなり見かけ上良好な样相を示し，貯藏 5 日間での 鮮度指数は各温度区とも変化はみられなかったが, 貯蔵 10日から全貯蔵区において鮮度指数の低下があきらかに 認められた。見かけ上良好なオクラさく果も，食品物性 および成分的には実質的にかなり品質が低下し，機器に よる測定值と肉眼での品質保持の差は貯蔵日数的にみれ ば 3 日前後の差を有することが認められた。適性貯蔵温 度は $-20^{\circ} \mathrm{C}$ であった。限界貯蔵日数は $1 \sim 5{ }^{\circ} \mathrm{C}$ で， 5 日, $20^{\circ} \mathrm{C}$ で $7 \sim 8$ 日, $10 \sim 15^{\circ} \mathrm{C}$ で15 18日, $-20^{\circ} \mathrm{C}$ で 25 日前後となった。

以上の結果から総合的に判断すれば，オクラさく果の 適性貯蔵温度は中温の $10 \sim 15^{\circ} \mathrm{C}$ で 25 日前後の貯蔵が可能 であり, 凍結区では生食以外のペースト状などでの調 理, 加工用としての大量利用などに適し，30日間の貯蔵 が可能であった。一方, 低温区の $1 \sim 5{ }^{\circ} \mathrm{C}$ およ゙常温区 $20^{\circ} \mathrm{C}$ では貯蔵性は極めて悪く, 貯蔵限界日数は $5 \sim 7$ 日 であった。

\section{要 約}

オクラさく果の鮮度保持性につき, 食品物性および成 分消長の点から開花結実後 6 日のグリーンスター変種を 用い検討した。さく果は緑色ネットと熱収縮ポリビニリ デンコロライドフィルムでシュリンクパック包装を行 い, 貯蔵温度は低温区として $1,5{ }^{\circ} \mathrm{C}$, 常温区は $20^{\circ} \mathrm{C}$,

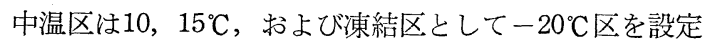
した。

\section{1. 食品物性}

針入度, 弾力度および粘性度とも低温貯蔵区および常 温区において貯蔵 $5 \sim 7$ 日で物性度は劣化し, さく果は “はり”を消失し, 萎稠軟化し腐敗一と進行し, 眝蔵限 界日数は $5 \sim 7$ 日であった。中温区および涷結区ではこ れらの現象は顕著に抑制され，25日前後の貯蔵が可能と なった。

\section{2. 色 調}

食品物性の劣化と類似した傾向を呈し，褐色化する が，測定值と肉眼観測值では見かけ上より測定值が 3 日 前後退色現象が早い。低温区では貯蔵限界日数は 10 日前 後であり, 中温区では20日前後, 凍結区では 30 日間の貯 蔵が可能であった。

\section{3. 総アスコルビン酸含有量の消失度}

食品物性の劣化より急速かつ高く，低温区および常温 区でこの傾向がとくに顕著であり，貯蔵限界日数は 5 日 前後であった。中温区，凍結区では低下様相は緩慢で低 下率はかなり抑制され貯蔵限界日数は25３0日となっ た。

\section{4. 総ペクチン含有量の消失度}

粘性度と極めて類似した傾向で低下した。食品物性度 および総アスコルビン酸含有量の低下速度より低温区に おいては 3〜 5 日遅延された。中温区，凍結区では貯蔵 初期にやや低下率流いが，貯蔵10日以後はほとんど低 下せず極めて安定した状態を呈し，貯蔵限界日数は低温 区で 7 10日前後, 中温区, 凍結区で25 30日間の貯蔵 が可能である。

オクラさく果の鮮度保持性は貯蔵温度に大きく左右さ れ, 適性貯蔵温度は $10 \sim 15^{\circ} \mathrm{C}$ であり, 生食以外ペースト 状などでの調理, 加工の大量利用ではー $20^{\circ} \mathrm{C}$ が良好であ る。低温貯蔵 $1 \sim 5{ }^{\circ} \mathrm{C}$ おび $20^{\circ} \mathrm{C}$ で㹥䝪蔵初期より大き く品質は劣化し, 貯藏限界日数は $5 \sim 7$ 日であった。

本研究の概要は昭和60年 9 月の本会関西講演会におい て発表した。

\section{引用文 献}

1) 大阪府立大学農学部園芸学教室編 : 園芸学実験 - 実習（養 賢堂), p. 282 (1981)

2 ）最新園芸大辞典編集委員会：最新園芸大辞典(4)（誠文堂新 光社), p.1943 (1976)

3) 大川德太郎ら : 食品材料学 ( 4 版) (医歯薬出版), p. 239, (1980)

4) KIRK, J.R. and Ting, N.,: J.Food Sci., 40, 463 (1975)

5) McСomb, E.A. and McCready, R.M.,: Anal, Cham., 24, 1630 (1952)

6) 大阪府立大学農学部園芸学教室編 : 園芸学実験 - 実習（㮹 堅堂), p.294 (1981)

7）桜井芳人ら : 冷凍食品ハンドブック (光琳書院), p. 185, (1976)

8）南出隆久・田村順介・緒方邦安：コールドチェーン研究, 5, 150 (1979)

9) Joslyn, M.A. and Marsh, G.L., : Observatin on THE EFFECT OF RATE OG FREEZING ON THE TEXTURE OF CERTAIN FRUITS AND vefETABles, Fruits prod. J.11 p. 327 (1932)

10）食品低温流通推進協議会編：食品の低温管理（農林統計協 会), p.141, (1975)

（昭和60年11月28日受理） 